\title{
Credit Card Debt and Payment Use
}

\section{Charles Sprenger and Joanna Stavins}

\begin{abstract}
:
Approximately half of credit card holders in the United States regularly carry unpaid credit card debt. These so-called "revolvers" exhibit payment behavior that differs from that of those who repay their entire credit card balance every month. Previous literature has focused on the adoption of debit cards by people who carry credit card balances, but so far there has been no empirical analysis exploring the relationship between revolving behavior and patterns of payment use, such as substitution away from credit cards to other payment methods.
\end{abstract}

Using data collected in the 2005 Survey of Consumer Payment Preferences, we explore the relationship between revolving credit card balances and payment use. We find that credit card revolvers are significantly more likely to use debit and less likely to use credit than convenience users who repay their balances each month. There is no significant difference between these two types of credit card users in their use of check or cash. The two groups differ in their perceptions of payments as well as in their payment behavior: revolvers are significantly less likely to view debit as superior with respect to ease of use and acceptability, but more likely to see debit as superior with respect to control over money and budgeting.

\section{JEL Classifications: D12, D14, E21}

keywords: payments, credit card, debit card, consumer credit

Charles Sprenger is a graduate student at the University of California, San Diego. Joanna Stavins is a senior economist and policy advisor at the Federal Reserve Bank of Boston. Their email addresses are, respectively, csprenger@ucsd.edu and joanna.stavins@bosfrb.org.

This paper, which may be revised, is available on the web site of the Federal Reserve Bank of Boston at http://www.bos.frb.org/economic/wp/index.htm.

We are grateful to Chris Foote, Stephan Meier, and Scott Schuh for helpful comments, and to Benjamin Levinger for research assistance.

The views expressed herein are solely those of the authors and not those of the Federal Reserve System or the Federal Reserve Bank of Boston.

This version: May 2008 


\section{Introduction}

Borrowing money on a credit card is expensive. Despite the cost, nearly 44 percent of credit card holders carry balances. ${ }^{1}$ Financing credit card borrowing represents a significant burden for U.S. households. The average debt level reported by individuals with card balances was around $\$ 5,000$ in 2004 (2004 dollars), financed at an average rate of over 11 percent per year (Bucks, Kennickell, and Moore 2006). Financial distress associated with managing such credit card debt may contribute to the high rates of personal bankruptcy filing (Domowitz and Sartain 1999; Stavins 2000; White 2007).

The high expense of carrying credit card debt, particularly in the face of the apparent availability of lower-cost alternative financing, has led researchers to examine the underlying determinants of card borrowing. This research has followed two primary paths. First, traditional (neoclassical) economic reasoning explains the carrying of high credit card debt as cost-minimizing behavior. According to that reasoning, financing consumption with credit cards may actually be less expensive, not more, than plausible alternatives, when costs associated with insufficient liquidity, arranging alternative financing, and switching credit contracts are fully taken into account. Second, a behavioral view of carrying credit card debt has associated card borrowing with self-control problems. Credit cards temporally separate the enjoyment of consumption from the pain of paying for it. This decoupling may be particularly attractive for individuals who disproportionately overvalue present consumption and undervalue future costs.

High levels of credit card debt and the consequences for the broader economy as well as for the individual debtor make the study of individuals who carry credit card balances an important topic in payments research. Whether the explanation is behavioral or traditional, the implications of credit card debt for payment behavior are similar. Cardholders who carry unpaid credit card balances - also called revolvers - face finance charges for their marginal purchases. Under the cost-based explanation, rational individuals should substitute from credit cards to alternative payment methods, provided they have sufficient liquidity to do so. Following the behavioral reasoning, individuals with credit card debt (and self-control problems) may substitute from credit cards to alternative payment methods as a self-control device.

Importantly, the two competing explanations of credit card debt generate hypotheses that, when tested, are observationally equivalent. Under either explanation, indi-

\footnotetext{
${ }^{1}$ Based on the 2004 Survey of Consumer Finances.
} 
viduals with revolving balances should use credit cards less and alternative payments more.

To date, evidence of such substitution by individuals with revolving balances has been lacking. Notable exceptions are Zinman (2007a) and Klee (2006), whose studies of credit card adoption both show that credit card revolvers are more likely than other credit card users to adopt debit cards. Although this is an important step towards explaining the payment behavior of revolvers, we argue that there is a significant difference between adopting a payment mechanism and actually using it at the point of sale. This paper attempts to further develop a picture of how carrying revolving balances impacts actual payment activity.

Using data from the Survey of Consumer Payment Preferences for over 1,800 individuals who hold both credit and debit cards, we explore the effects of revolving balances on payments made with four different payment methods: credit card, debit card, check, and cash. We find significant evidence of substitution of debit for credit by individuals with unpaid credit card balances. Individuals who regularly carry revolving balances make a significantly lower fraction of their total payments with credit and a significantly higher fraction of their total payments with debit. In contrast, there is no significant difference in the use of check or cash between revolvers and convenience users. Furthermore, revolvers are much more likely than convenience users to report debit as being the payment method chosen most frequently at the point of sale. Unlike the previous literature related to this topic, this study addresses the actual use of payment instruments by revolvers.

We complement our analysis of payment behavior with qualitative data on payment attribute perceptions. Perceptions - or perceived differences in payment attributeshave been found to be important determinants of consumer payment behavior (see Hirschman 1982; Miyazaki and Fernandez 2001; Mantel 2000; Jonker 2005; Schuh and Stavins 2008). We attempt to identify revolvers' perceptions of debit cards that may be linked to their substitution behavior. We show that individuals with revolving balances are much more likely than convenience users to feel that debit offers superior budgeting and control over money than credit. Such attribute perceptions are likely to be important determinants of payment substitution.

Our results are the first to show substitution from credit to debit by individuals with revolving credit card balances, not only in the adoption of payment methods, but in actual payment use. This substitution is likely motivated by concerns of budgeting 
and financial control. Provided that perceptions are not fixed over time, our results also point to key attribute perceptions that marketers and policymakers can influence to affect credit card spending.

The paper is organized as follows: Section 2 reviews the literature on credit card revolving, discussing implications for payment behavior. Section 3 describes the data. Section 4 presents our results and Section 5 concludes.

\section{Literature Review}

Carrying credit card balances from month to month is an apparently expensive way to finance consumption. This high cost has motivated two broad paths of research seeking to explain the underlying determinants of holding such revolving balances. The first, more traditional path attempts to explain credit card debt with cost-based explanations. The second path, behavioral in nature, has sought to explain credit card debt with psychological factors such as self-control problems.

Traditional economic explanations for credit card debt are based on analysis of the relative cost of credit card borrowing compared with other sources of credit. Although credit card borrowing may seem expensive, some economists suggest that alternatives may be even more costly. The price of borrowing may include not only the interest rate, but also the difficulty of arranging alternative financing and the costs of switching across credit contracts.

Brito and Hartley (1995) indicate that the cost of paying interest on credit card debt is likely to be lower than the transaction costs associated with arranging loans from banks or other financial institutions. Telyukova and Wright (2005) and Zinman (2007b) show that consumers maintain balances in their low-interest-bearing bank accounts for liquidity reasons, even while carrying high-interest credit card debt. The authors suggest that a rational consumer may pay interest on credit card debt to avoid some of the expected costs associated with not holding precautionary or transactions balances. Researchers have also argued that high costs of switching credit contracts may play a role in consumers' decision to maintain balances on their credit cards (see Calem

and Mester 1995; Calem, Gordy, and Mester 2005; Ausubel and Shui 2005). These traditional cost-based explanations show that credit card debt, despite high interest rates, may actually be a lower-cost source of financing than other options. This view is 
supported by evidence suggesting that the actual value of credit card debt is negatively correlated with changes in interest rates, showing price sensitivity in card borrowing (Gross and Souleles 2002).

Traditional cost-based explanations are somewhat at odds with a growing body of behavioral research on credit card borrowing. Laibson, Repetto, and Tobacman (2000) use a model of a consumer with self-control problems to explain the household portfolio puzzle of holding both credit card debt and low-interest illiquid assets, such as retirement accounts. Meier and Sprenger (2007) show that directly measured selfcontrol problems are strongly correlated with credit card debt. Ausubel (1991) suggests that self-control problems play a primary role in generating credit card industry profits; and Ausubel and Shui (2005) indicate that self-control problems can explain the success of teaser rates in credit card markets.

The nature of credit cards may make credit card spending (and borrowing) particularly susceptible to self-control problems. Behavioral research on credit card use highlights decoupling: the separation of payment decisions from consumption decisions (for discussions, see Prelec and Lowenstein 1998; Thaler 1999). With a credit card, payment is separated from the act of purchasing and can occur substantially later than purchase or consumption. Psychologically, such temporal separation may encourage credit card spending and, consequently, credit card debt (Bar-Gill 2004).

For the purpose of this paper, we do not specifically endorse either the traditional or the behavioral view of credit card borrowing. Instead, we seek to understand the payment patterns of credit card borrowers, and the two views generate hypotheses that, when tested, are observationally equivalent. That is, under both views, individuals with revolving balances are more likely than convenience users to use alternative payment media at the point of sale.

Under the traditional view, consumers minimize their costs. Credit card revolvers with no liquidity constraints would choose not to borrow, in order to avoid the cost of financing. In this cost-based approach, a rational consumer would choose the lower-cost option, that is, a rational consumer would use credit less, and other payment methods more.

The behavioral view would see the use of alternative payment instruments as an act of will, a commitment device chosen by an individual who has self-control problems with respect to credit card spending. In this view, individuals with revolving balances are the ones with such self-control problems. Even though only "sophisticated" individuals, 
cognizant of their self-control problems, would take up such a commitment device, one would expect revolvers to be more likely than non-revolvers to choose alternative payment methods, all else being constant.

Zinman (2007a) and Klee (2006) have shown that individuals who carry revolving credit card balances are significantly more likely than convenience users to adopt debit. There is a critical difference between adopting a payment instrument and actually using it at the point of sale. Individuals with self-control problems may obtain a debit card as a commitment device, but fail to act as intended (use the debit card) when making purchases. Furthermore, revolvers who face liquidity constraints (see Telyukova and Wright 2005; Zinman 2007b) may use credit more than individuals without revolving balances, in order to avoid insufficient liquidity.

Although the issue of payment instrument adoption by individuals with revolving credit card balances has been addressed in the literature, empirical evidence showing the relationship between revolving balances and payment use, such as the substitution of debit for credit, has been lacking. Using data collected from the 2005 Survey of Consumer Payment Preferences specifically tailored to addressing these issues, we explore the relationship between revolving credit card balances and payment use.

\section{Data: The Survey of Consumer Payment Prefer- ences}

We use survey data specifically tailored to answering the question of how revolving credit card balances are related to payment method use. In the spring of 2005, Dove Consulting, jointly with the American Bankers Association, conducted its fourth biannual payments survey, the Study of Consumer Payment Preferences (SCPP). The survey was either distributed by mail or administered on the Internet; 3,008 individuals over 18 years of age across the United States responded, with a response rate of approximately 15 percent. $^{2}$

Even though the SCPP sample is supposed to be representative of the United States population, there are concerns about sample selection that could impact both the generality and the validity of our results. There are issues of sample selection bias with

\footnotetext{
${ }^{2}$ Of the 3,008 respondents, 2,350 completed web-based surveys, and the remaining 658 submitted surveys by mail.
} 
respect to: (1) survey recipients and (2) survey respondents. The SCPP survey was sent to individuals from a list generated by a private marketing firm. The process of choosing recipients appears not to have been a random selection of individuals from the population. In order to induce responses, three $\$ 1,000$ lottery prizes were offered to respondents. The presence of this lottery likely generates differences between respondents and nonrespondents. Respondents may have a lower opportunity cost of time and/or be more risk-loving than nonrespondents.

In addition to these potential sample selection issues, there are demographic differences between the SCPP sample and the broader population. SCPP survey respondents have, on average, higher levels of education and are more likely to be in middle age and income groups when compared with the U.S. population. Previous research has shown the importance of such demographic characteristics for payment behavior (see, for example, Stavins 2001; Mester 2003; Anguelov, Hilgert, and Hogarth 2004). Despite not being fully representative of the U.S. population, the SCPP contains a depth of information on payment behavior and consumer perceptions of payments not available from any other survey to date. ${ }^{3}$

To explore the relationship between revolving credit card balances and payment use at the point of sale, we take a subsample of SCPP respondents. Our analysis focuses on the 62.5 percent of the sample, 1,880 individuals, who hold both credit and debit cards and have non-missing socio-demographic characteristics and paymentrelated responses (see below). Forty-three percent of the sample, or 807 individuals, report regularly carrying balances on their credit cards. ${ }^{4}$

Table 1 shows the socio-demographic characteristics of individuals included in our analysis for all cardholders, revolvers, and convenience users. Individuals in the sample are predominantly white, under 45 years old, with at least some college education and income between $\$ 40,000$ and $\$ 100,000$. On average, people in the sample have reasonably high levels of financial experience: the average length of time for which a person has held his or her primary checking account exceeds 11 years. As can be seen, there are few differences in socio-demographic characteristics between individuals who do and do not carry credit card balances. Individuals with revolving balances are

\footnotetext{
${ }^{3}$ Schuh and Stavins (2008) explore other data on payment behavior and perceptions of payments.

${ }^{4}$ The question was worded as "I regularly carry a balance on my credit card (do not pay off the balance in full)." The fraction of revolvers is almost identical to that in the 2004 Survey of Consumer Finances, where approximately 44 percent of credit card holders carried balances (authors' calculation).
} 
generally younger than those who repay their balances. In the following sections, we test whether the two groups of cardholders differ in their payment behavior.

\subsection{Payment Use}

Our primary measures of payment use at the point of sale are: (1) the fraction of total payments made with a given payment instrument and (2) the payment instrument cited as the one most frequently used at the point of sale.

The survey asks respondents to indicate how many purchases they make with a given payment instrument in stores in a given week. The question is worded as, "How often do you use the following payment methods to make purchases in stores?" The options are "Don't use, Once a week or less, 2-4 times per week, 5-7 times per week, or 8 or more times per week."

For payments made with credit card, debit card, check, and cash we take the midpoint of the interval response as the number of payments made. ${ }^{5}$ For each payment instrument, we take the number of payments made with payment $j$, and divide by the total number of payments made by consumer $i$, to obtain the fraction of purchases made by consumer $i$ with payment $j$.

$$
\text { Fraction }_{i j}=\frac{N_{i j}}{\sum_{p \in\{\text { Credit }, \text { Debit }, \text { Cash }, \text { Check }\}} N_{i p}}
$$

where $N_{i j}$ is the number of payments made by consumer $i$ with payment $j$.

The resulting variables Fraction Credit, Fraction Debit, Fraction Check, and Fraction Cash are used as dependent variables in our analysis.

In addition to asking respondents about a total number of payments, the survey also asks respondents to state which payment instrument they use most frequently at the point of sale. The question is worded as, "When you make purchases overall, which method of payment do you use most often?"

Responses to this question generate four binary variables used in our analysis:

\footnotetext{
${ }^{5}$ In the SCPP data, the highest response, "> 8 payments," is top-coded as 10 . The results are robust to variations in this top-coding. The lowest response is coded as zero.
} 
Most Frequent Credit, Most Frequent Debit, Most Frequent Check, and Most Frequent Cash. These variables are equal to 1 if the given payment instrument is chosen most frequently, and 0 otherwise.

In addition to these payment behavior variables, the survey also asks respondents to report their participation in credit and debit card rewards programs. Such program participation changes the relative price of using a certain payment instrument and so represents an important determinant of payment behavior (for evidence, see Ching and Hayashi 2006). Of our sample of 1,880 individuals, 1,722 answered the question that asked whether or not they had either debit card or credit card rewards, or both.

Summary statistics for these payment variables are presented in Table 2 by revolving behavior. Unlike the demographic variables, these variables show that individuals with revolving balances exhibit payment patterns that differ significantly from those of convenience users. Even though cash and check payment behavior is similar across revolvers and convenience users, revolvers show significant substitution from credit to debit. Individuals with revolving balances cite a significantly lower fraction of total payments made with credit and a higher fraction of total payments made with debit. Revolvers are also significantly more likely to cite debit, and significantly less likely to cite credit, as their primary payment choice.

\subsection{Perceptions of Payments}

In addition to asking about payment use, the SCPP asks a series of questions on individual perceptions of payment instruments. The responses to these questions allow us to explore the underlying reasons for the payment behavior that consumers report. For each payment instrument, respondents were asked whether they view it as: easy to use, widely acceptable, safe, allowing control over money, helping in budgeting, and easy to get refunds or resolve disputes (for the design of these survey questions, please see the appendix). Individuals responded either yes or no to each question, for each payment instrument.

The perceptions of payments elicited in the SCPP provide an opportunity to see what consumers view as salient features for each payment instrument and to see how these perceptions affect payment use. For the purposes of this paper, we are primarily interested in the consumers' perceptions of debit cards and credit cards.

We use responses to the above perception questions to generate six binary variables 
that are equal to 1 if the respondent answered "Yes," and 0 if the respondent answered "No"; these variables are: Easy, Acceptable, Safe, Control, Budgeting, and Refund. Further, we generate binary variables that are equal to 1 if the survey respondent answered positively in the case of debit and negatively in the case of credit - that is, they show whether or not the respondent perceives a clear difference between debit and credit, and perceives debit as superior. The following six variables are used in our analysis of perceptions: DebitBetterEasy, DebitBetterAcceptable, DebitBetterSafe, DebitBetterControl, DebitBetterBudgeting, and DebitBetterRefund.

Table 3 shows summary statistics of these variables, broken down by revolving behavior, for individuals with non-missing socio-demographic characteristics. Individuals with revolving balances are significantly less likely to see debit as superior to credit with respect to ease of use and acceptability, significantly more likely to see debit as being better with respect to control over money and budgeting, and to see no significant difference between the two payment methods for safety and ease of refunds.

The $t$-tests presented in Table 3 indicate that individuals with revolving balances are significantly more likely to view debit as better than credit in terms of budgeting and control over money. These may be key perceptual differences associated with revolvers' substitution of debit for credit.

In the next section, we further explore differences in payment behavior associated with revolving balances, controlling for socio-demographic characteristics and partici-

pation in rewards programs. We also study how perceptions are related to revolving behavior, controlling for socio-demographic characteristics and rewards program participation.

\section{Results}

\subsection{Revolving Balances and Payment Behavior}

\subsubsection{Revolving Balances and Fraction of Payments}

Both behavioral and traditional approaches to revolving credit card debt suggest that individuals who carry a balance on their credit cards should be more likely, all else being equal, to substitute away from credit cards and into alternative payment methods for purchases. We would expect revolving balances to be associated with a lower fraction 
of credit card payments and a higher fraction of debit, check, and cash payments. In Table 4 we present ordinary least squares regressions of the following form, with robust standard errors:

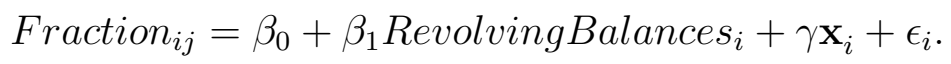

Fraction $_{i j}$ is the fraction of payments made by consumer $i$, using payment $j$. RevolvingBalances $_{i}$ is a binary variable taking the value 1 if an individual regularly carries a credit card balance and 0 otherwise. $\mathbf{x}_{i}$ is a vector of socio-demographic and other characteristics of consumer $i$, which varies with specification but always includes categorical variables for gender, age group, income group, race, education, and a continuous variable for the length of time in years that an individual has held his or her current checking account. The socio-demographic variables are defined as shown in Table 1. Extended results of these regressions are displayed in Table 5.

In Columns 1 and 2 of Table 4 we present regressions with FractionCredit as the dependent variable. In the initial specification of Column 1, we find, controlling for socio-demographics, that having revolving credit card balances is associated with a significant reduction in the fraction of payments for which credit cards are used. In Column 2, we additionally control for participation in credit and debit card rewards programs. ${ }^{6}$ Some of the demographic characteristics and the presence or absence of rewards program participation are important determinants of the fraction of payments for which credit cards are used. Across specifications, we find that revolving balances are associated with a reduction of between 2 and 4 percent in the fraction of payments for which credit cards are used.

In Columns 3 and 4 of Table 4 we present regressions with FractionDebit as the dependent variable. Socio-demographic characteristics, along with rewards program participation, have strong effects on the fraction of payments for which debit is used. We find evidence for substitution into debit cards by individuals with revolving balances. Controlling for socio-demographic characteristics and rewards program participation, we find that revolving balances are associated with an increase of 4 to 5 percent in the fraction of payments made by debit card.

It seems that, for individuals with revolving balances, the reduction in credit card

\footnotetext{
${ }^{6}$ Although rewards program participation may be endogenous, including it in the regression does not change our results.
} 
payments is almost entirely offset by additional debit card payments. In Columns 5 and 6 of Table 4 we present regressions with FractionCash as the dependent variable. We find no significant increases associated with revolving balances in the fraction of payments for which cash is used. If anything, the implication is that revolvers use cash for a smaller fraction of payments than do convenience users. In Columns 7 and 8 of Table 4, we present regressions with FractionCheck as the dependent variable. We also find no impact of revolving balances on the fraction of payments for which checks are used.

\subsubsection{Revolving Balances and Most Frequently Used Payment}

Evidence of substitution from credit cards to debit cards for payments is further supported when we examine the payment instrument individuals cite as the one most frequently used at the point of sale. In Table 6 we present results from logistic regressions with robust standard errors of the following form:

$$
\text { MostFrequent }_{i j}=\beta_{0}+\beta_{1} \text { RevolvingBalances }_{i}+\gamma \mathbf{x}_{i}+\epsilon_{i} \text {. }
$$

MostFrequent $t_{i j}$ is a dummy variable equal to 1 if consumer $i$ reports using payment $j$ most frequently. As before, RevolvingBalances $s_{i}$ is a binary variable indicating whether an individual regularly carries a credit card balance, and $\mathbf{x}_{i}$ is a vector of socio-demographic and other characteristics of consumer $i$. Extended results of these regressions are displayed in Table 7.

The results in Table 6 largely confirm the evidence presented in Table 4. Individuals with revolving balances are significantly less likely to cite credit card as the payment instrument most frequently used at the point of sale, controlling for socio-demographic characteristics and rewards program participation. The calculated odds ratio indicates that revolvers are around half as likely as convenience users to use credit cards most frequently.

Individuals with revolving balances are, however, significantly more likely than convenience users to cite debit card as the payment instrument most frequently used. Calculated odds ratios indicate that revolvers are nearly one-and-a-half times more likely to use debit cards most frequently. There is no apparent difference between the two groups in the likelihood of citing cash as the most frequently used payment instrument. Revolvers are more likely to cite check as their most frequently used 
payment instrument, although this effect becomes insignificant after controlling for credit card and debit card rewards.

\subsection{Revolving Balances and Qualitative Perceptions}

While we find strong evidence in support of substitution from credit cards to debit cards for individuals who regularly carry revolving balances, the finding provides little insight into the reasons for the substitution. That is, we do not know whether the substitution is carried out because individuals with revolving balances seek to curb their spending (according to the behavioral theory), to avoid financing costs (according to the traditional neoclassical theory), or for some other reason not captured in our data.

The survey asks a series of qualitative questions related to perceptions about individual payments. The literature has supported the view that attribute perceptions are strongly associated with payment behavior (for evidence and discussions see Hirschman 1982; Miyazaki and Fernandez 2001; Mantel 2000; Jonker 2005; Schuh and Stavins 2008).

Given that perceptions are important factors in payment behavior, we are interested in the following question: Which payment attributes do consumers with revolving balances perceive as different between debit and credit in a manner that may influence their payment substitution? This question is important, as it may provide support for either the traditional view, the behavioral view, or neither.

The results shown in Table 3 indicate that budgeting and control over money may be the key differences in revolvers' perceptions associated with their substitution from credit to debit. This view is supported by regression results. In Table 8 we present results from logistic regressions with robust standard errors of the following form:

$$
\text { DebitBetter }_{i j}=\beta_{0}+\beta_{1} \text { RevolvingBalances }_{i}+\gamma \mathbf{x}_{i}+\epsilon_{i} \text {. }
$$

DebitBetter $_{i j}$ is a dummy variable that equals 1 if consumer $i$ approves of debit cards but not credit cards for that specific perception $j$. RevolvingBalances $s_{i}$ is a binary variable taking the value 1 if an individual regularly carries a credit card balance and 0 otherwise. $\mathbf{x}$ is a vector of socio-demographic characteristics and variables for rewards program participation. Extended results of these regressions are displayed in Table 9. 
Individuals with revolving balances are significantly less likely than convenience users to indicate that debit is better than credit when it comes to ease, acceptability, and refunds. We would expect such differences to increase the use of credit, not decrease it as seen in the data. Revolvers are significantly more likely to indicate that debit is better than credit in terms of budgeting and control. We argue that these perceptions of superior budgeting and control over money may be the key factors in revolvers' substitution from credit to debit. Even though revolvers are less likely to perceive debit as easier to use than credit, they use it more frequently because of the importance to them of budgeting and control over money.

Given the nature of the data and the fact that the questions are open to individual interpretation, it is difficult to parse behavioral and traditional views from perception responses. Budgeting and control over money could be interpreted traditionally as avoiding finance charges, or behaviorally as imposing self-control. We cannot determine whether these results support the behavioral or traditional view of credit card debt, although the behavioral approach is consistent with our findings. Importantly, however, we do not find support for there being another reason why having revolving balances is associated with substitution of debit for credit.

Although previous research has found that individuals with revolving balances are more likely than convenience users to adopt debit cards, there are critical differences between adoption and use. We find that individuals with revolving credit balances are also more likely to use debit than credit for point-of-sale purchases. We argue that this substitution is associated with a perception on the part of credit card revolvers that debit cards can help them to budget better and have more control over their money.

\section{Conclusion}

Approximately half of credit card holders in the United States regularly carry unpaid credit card debt. These so-called revolvers exhibit different payment behavior from those who repay their credit card balances every month. Previous research has found that individuals with revolving balances are more likely to adopt debit cards, but so far there have been no empirical studies exploring the relationship between credit card revolving and payment use patterns, such as substitution away from credit cards to other payment methods. 
Using data collected in the 2005 Survey of Consumer Payment Preferences, we explore the relationship between revolving credit card balances and payment use. We find that credit card revolvers are significantly more likely to use debit and less likely to use credit, as compared with convenience users who repay their balances each month. We find no significant differences in the use of check or cash between the two groups. The two groups also differ in their perceptions of payments - revolvers are significantly less likely to view debit as superior with respect to ease of use and acceptability, but more likely to see debit as better with respect to control over money and budgeting. The findings suggest that revolvers not only adopt, but also use, debit more frequently than convenience users do, in order to control their spending. 


\section{References}

Anguelov, C. E., M. A. Hilgert, and J. M. Hogarth. 2004. "U.S. Consumers and Electronic Banking, 1995-2003." Federal Reserve Bulletin, Winter, pp. 1-18.

Ausubel, L. 1991. "The Failure of Competition in the Credit Card Market." The American Economic Review 81:50-81.

Ausubel, L., and H. Shui. 2005. "Time Inconsistency in the Credit Card Market." Mimeo.

Bar-Gill, O. 2004. "Seduction by Plastic." Northwestern University Law Review 98:1374-1434.

Brito, D., and P. Hartley. 1995. "Consumer Rationality and Credit Cards." Journal of Political Economy 103:400-433.

Bucks, B., A. Kennickell, and K. Moore. 2006. "Recent Changes in .S. Family Finances: Evidence from the 2001 and 2004 Survey of Consumer Finances." Federal Reserve Bulletin 92:A1-A38.

Calem, P., M. Gordy, and L. Mester. 2005. "Switching Costs and Adverse Selection in the Market for Credit Cards: New Evidence." Mimeo.

Calem, P., and L. Mester. 1995. "Consumer Behavior and the Stickiness of Credit Card Interest Rates." American Economic Review 85:1327-1336.

Ching, A., and F. Hayashi. 2006. "Payment Card Rewards Programs and Consumer Payment Choice." Mimeo.

Domowitz, I., and R. Sartain. 1999. "Determinants of the Consumer Bankruptcy Decision." Journal of Finance 54:403-420.

Gross, D., and N. S. Souleles. 2002. "Do Liquidity Constraints and Interest Rates Matter for Consumer Behavior? Evidence from Credit Card Data." Quarterly Journal of Economics 117:149-185.

Hirschman, E. 1982. "Consumer Payment Systems: The Relationship of Attribute Structure to Preference and Usage." Journal of Business 55:531-545. 
Jonker, N. 2005. "Payment Instrument as Perceived by Consumers A Public Survey." Mimeo.

Klee, E. C. 2006. "Families Use of Payment Instruments During a Decade of Change in the U.S. Payment System." Board of Governors of the Federal Reserve System. Finance and Economics Discussion Series 2006-01.

Laibson, D., A. Repetto, and J. Tobacman. 2000. “A Debt Puzzle.” Mimeo.

Mantel, B. 2000. "Why Do Consumers Pay Bills Electronically? An Empirical Analysis." Federal Reserve Bank of Chicago Economic Perspectives 25:32-48.

Meier, S., and C. Sprenger. 2007. "Impatience and Credit Behavior: Evidence from a Field Experiment." Working paper No. 07-3, Federal Reserve Bank of Boston.

Mester, L. J. 2003. "Changes in the Use of Electronic Means of Payment: 1995-2001." Federal Reserve Bank of Philadelphia Business Review Q3:18-20.

Miyazaki, A., and A. Fernandez. 2001. "Consumer Perceptions of Privacy and Security Risks for Online Shopping." The Journal of Consumer Affairs 35:27-44.

Prelec, D., and G. Lowenstein. 1998. "The Red and the Black: Mental Accounting of Savings and Debt." Marketing Science 17:4-28.

Schuh, S., and J. Stavins. 2008. "To Check or Not to Check: Why Are (Some) Consumers (Finally) Writing Fewer Checks?" Mimeo.

Stavins, J. 2000. "Credit Card Borrowing, Delinquency and Personal Bankruptcy." New England Economic Review, July, pp. 15-30.

—. 2001. "Effect of Consumer Characteristics on the use of Payment Instruments." Federal Reserve Bank of Boston New England Economic Review 3Q:19-31.

Telyukova, I., and R. Wright. 2005. "A Model of Money and Credit with Application to the Credit Card Debt Puzzle." Mimeo.

Thaler, R. 1999. "Mental Accounting Matters." Journal of Behavioral Decision Making 12:183-206.

White, M. 2007. "Bankruptcy Reform and Credit Cards." Journal of Economic Perspectives 21(4):175-199. 
Zinman, J. 2007a. "Debit or Credit?" Mimeo.

. 2007b. "Household Borrowing High and Lending Low Under No-Arbitrage." Mimeo. 
Table 1: Demographic Variable Means by Credit Card Revolving Behavior

\begin{tabular}{lcccc}
\hline Variable & $\begin{array}{c}\text { Total } \\
\mathrm{N}=1880\end{array}$ & $\begin{array}{c}\text { Convenience Users } \\
\mathrm{N}=1073\end{array}$ & $\begin{array}{c}\text { Revolvers } \\
\mathrm{N}=807\end{array}$ & $\begin{array}{c}\text { p-value } \\
\text { from t-test }\end{array}$ \\
\hline & & & & \\
Revolving Balances (=1) & .429 & 0 & 1 & \\
Male & .509 & .513 & .503 & .684 \\
Age & & & & \\
Over 65 yrs & .099 & .116 & .078 & .007 \\
55-64 yrs & .211 & .231 & .183 & .012 \\
45-54 yrs & .177 & .176 & .178 & .897 \\
35-44 yrs & .245 & .219 & .280 & .002 \\
25-34 yrs & .204 & .186 & .228 & .027 \\
18-24 yrs & .063 & .072 & .052 & .082 \\
Race & & & & \\
Other & .044 & .048 & .038 & .294 \\
Hispanic & .069 & .063 & .076 & .300 \\
White & .702 & .706 & .695 & .598 \\
Asian & .064 & .065 & .062 & .774 \\
Black & .122 & .116 & .129 & .417 \\
Income & & & & \\
>\$150K & .031 & .035 & .025 & .187 \\
\$100-\$149K & .096 & .097 & .094 & .841 \\
\$60-\$99K & .277 & .257 & .304 & .026 \\
\$40-\$59K & .248 & .250 & .245 & .826 \\
\$20-\$39K & .246 & .248 & .244 & .850 \\
$<$ \$20K & .102 & .113 & .088 & .079 \\
Education & & & & \\
Grad. School & .141 & .150 & .130 & .220 \\
College & .310 & .313 & .306 & .743 \\
Some College & .380 & .376 & .387 & .626 \\
High School & .157 & .148 & .169 & .230 \\
Some HS & .011 & .013 & .009 & .372 \\
Add'l Cntrls & & & & \\
Check Account Years & 11.5 & 11.6 & 11.4 & .604 \\
& & & &
\end{tabular}


Table 2: Average Payment Method Use by Credit Card Revolving Behavior

\begin{tabular}{lcccc}
\hline Variable & $\begin{array}{c}\text { Total } \\
\mathrm{N}=1880\end{array}$ & $\begin{array}{c}\text { Convenience Users } \\
\mathrm{N}=1073\end{array}$ & $\begin{array}{c}\text { Revolvers } \\
\mathrm{N}=807\end{array}$ & $\begin{array}{c}\mathrm{p} \text {-value } \\
\text { from t-test }\end{array}$ \\
\hline & & & & \\
Fraction of Payments & & & & \\
Made at Point of Sale & & & & \\
Credit Card & .213 & .233 & .186 & .000 \\
Debit Card & .363 & .338 & .397 & .000 \\
Cash & .308 & .316 & .298 & .087 \\
Check & .116 & .113 & .119 & .418 \\
& & & & \\
Fraction Citing & & & & \\
Payment Type as Most & & & & \\
Frequently Used at & & .277 & .183 & .000 \\
Point of Sale & .237 & .341 & .450 & .000 \\
Credit Card & .388 & .339 & .304 & .102 \\
Debit Card & .324 & .043 & .063 & .049 \\
Cash & .052 & & &
\end{tabular}

Table 3: Fraction of Consumers Reporting Debit Better than Credit

\begin{tabular}{lcccc}
\hline Variable & $\begin{array}{c}\text { Total } \\
\mathrm{N}=1722\end{array}$ & $\begin{array}{c}\text { Convenience Users } \\
\mathrm{N}=964\end{array}$ & $\begin{array}{c}\text { Revolvers } \\
\mathrm{N}=758\end{array}$ & $\begin{array}{r}\mathrm{p} \text {-value } \\
\text { from t-test }\end{array}$ \\
\hline $\begin{array}{l}\text { Debit Better than } \\
\text { Credit for... }\end{array}$ & & & & \\
Easy & .167 & .200 & .125 & .000 \\
Acceptability & .171 & .186 & .152 & .063 \\
Safe & .278 & .275 & .281 & .779 \\
Control & .631 & .598 & .674 & .001 \\
Budget & .442 & .405 & .489 & .000 \\
Refund & .146 & .158 & .131 & .114
\end{tabular}




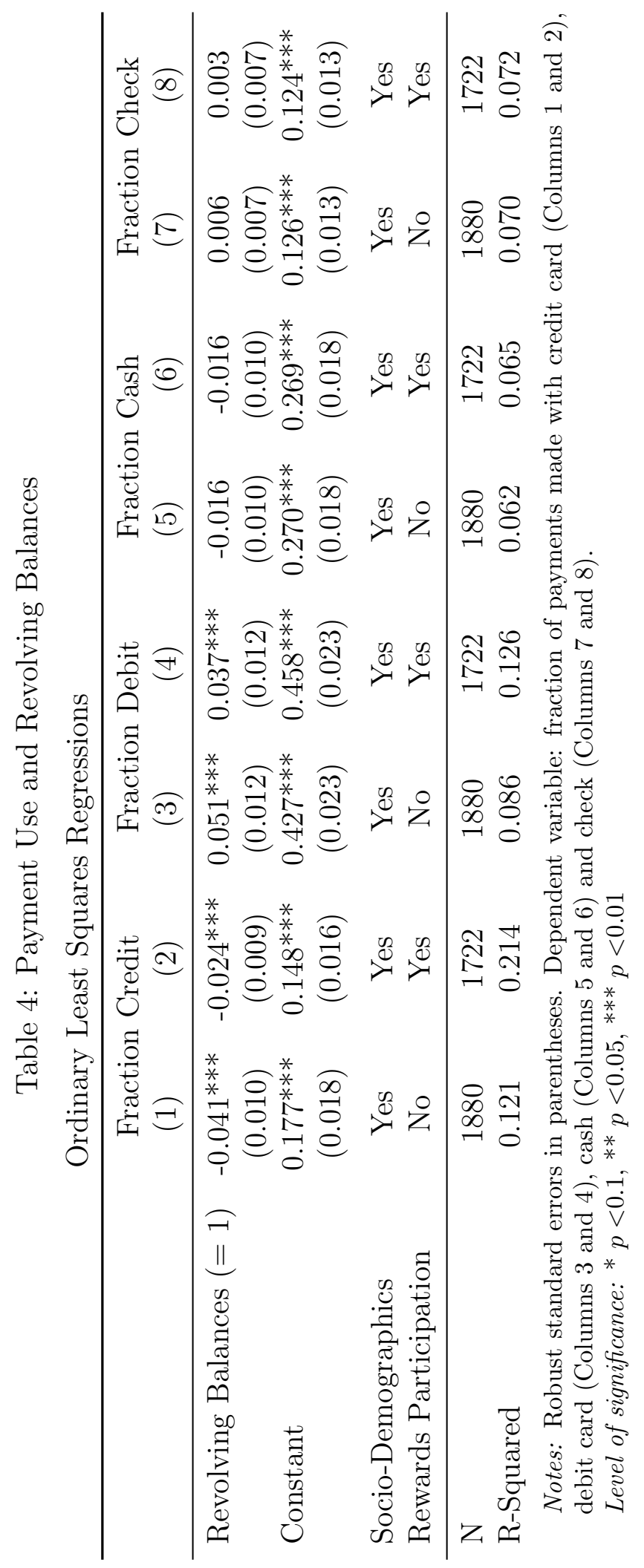


Table 5: Payment Use and Revolving Balances: Ordinary Least Squares Regressions

\begin{tabular}{|c|c|c|c|c|c|c|c|c|}
\hline & \multicolumn{2}{|c|}{ Fraction Credit } & \multicolumn{2}{|c|}{ Fraction Debit } & \multicolumn{2}{|c|}{ Fraction Cash } & \multicolumn{2}{|c|}{ Fraction Check } \\
\hline & $(1)$ & $(2)$ & $(3)$ & (4) & $(5)$ & $(6)$ & $(7)$ & (8) \\
\hline $\begin{array}{l}\text { Revolving } \\
\text { Balances }(=1)\end{array}$ & $-0.041^{* * *}$ & $-0.024^{* * *}$ & $0.051^{* * *}$ & $0.037^{* * *}$ & -0.016 & -0.016 & 0.006 & 0.003 \\
\hline $\begin{array}{l}\text { Male } \\
\text { Age }\end{array}$ & 0.010 & 0.010 & $-0.047^{* * *}$ & $-0.044^{* * *}$ & $0.069 * * *$ & $0.066^{* * *}$ & $-0.031^{* * *}$ & $-0.032^{* * *}$ \\
\hline $\begin{array}{l}\text { Over } 65 \text { yrs } \\
55-64 \text { yrs }\end{array}$ & $0.064^{* * *}$ & $0.036^{*}$ & $-0.071^{* * *}$ & $-0.050 * *$ & -0.020 & -0.021 & $0.027^{*}$ & $0.036^{* *}$ \\
\hline $45-54$ yrs & -0.026 & -0.021 & 0.006 & 0.006 & $0.028^{*}$ & 0.020 & -0.008 & -0.006 \\
\hline $35-44$ yrs & -0.010 & -0.016 & 0.018 & 0.022 & -0.008 & -0.011 & -0.000 & 0.005 \\
\hline $25-34$ yrs & 0.004 & -0.006 & $0.044^{* *}$ & $0.048 * *$ & -0.012 & -0.014 & $-0.036^{* * *}$ & $-0.028^{* *}$ \\
\hline $\begin{array}{l}18-24 \text { yrs } \\
\text { Race }\end{array}$ & 0.003 & 0.002 & 0.016 & 0.012 & 0.030 & 0.025 & $-0.048^{* * *}$ & $-0.038^{* * *}$ \\
\hline Other & $-0.045^{* *}$ & -0.026 & $0.059 * *$ & 0.045 & 0.008 & 0.004 & -0.022 & -0.022 \\
\hline $\begin{array}{l}\text { Hispanic } \\
\text { White }\end{array}$ & 0.002 & 0.016 & 0.019 & -0.006 & -0.003 & 0.005 & -0.018 & -0.015 \\
\hline Asian & $0.122^{* * *}$ & $0.126^{* * *}$ & $-0.119 * * *$ & $-0.121 * * *$ & -0.006 & -0.001 & 0.002 & -0.004 \\
\hline Black & $-0.055^{* * *}$ & $-0.031^{* *}$ & 0.013 & -0.015 & $0.072^{* * *}$ & $0.070^{* * *}$ & $-0.030 * * *$ & $-0.024^{* * *}$ \\
\hline Income & & & & & & & & \\
\hline$>\$ 150 \mathrm{~K}$ & $0.116^{* * *}$ & 0.054 & $-0.068^{*}$ & -0.030 & -0.007 & 0.008 & $-0.041^{* *}$ & $-0.032^{*}$ \\
\hline$\$ 100-\$ 149 \mathrm{~K}$ & $0.093^{* * *}$ & $0.067^{* * *}$ & $-0.053^{* *}$ & -0.037 & -0.027 & -0.022 & -0.013 & -0.008 \\
\hline$\$ 60-\$ 99 \mathrm{~K}$ & $0.034^{* *}$ & 0.018 & -0.016 & -0.005 & -0.020 & -0.016 & 0.002 & 0.003 \\
\hline$\$ 40-\$ 59 \mathrm{~K}$ & 0.002 & -0.003 & -0.001 & 0.012 & -0.008 & -0.014 & 0.007 & 0.005 \\
\hline $\begin{array}{l}\$ 20-\$ 39 \mathrm{~K} \\
<\$ 20 \mathrm{~K}\end{array}$ & -0.001 & 0.020 & $-0.058^{* *}$ & $-0.068^{* * *}$ & $0.053^{* *}$ & $0.044^{* *}$ & 0.007 & 0.004 \\
\hline Education & & & & & & & & \\
\hline Grad. School & $0.106^{* * *}$ & $0.076^{* * *}$ & $-0.076^{* * *}$ & $-0.062 * * *$ & -0.023 & -0.017 & -0.007 & 0.002 \\
\hline $\begin{array}{l}\text { College } \\
\text { Some College }\end{array}$ & $0.040^{* * *}$ & $0.023^{*}$ & -0.015 & -0.011 & $-0.024^{* *}$ & -0.016 & -0.001 & 0.004 \\
\hline High School & -0.018 & -0.016 & $-0.046^{* *}$ & $-0.048^{* * *}$ & $0.035^{* *}$ & $0.038^{* *}$ & $0.028^{* *}$ & $0.026^{* *}$ \\
\hline Some HS & -0.047 & -0.023 & 0.047 & 0.002 & 0.042 & 0.057 & $-0.041^{*}$ & $-0.037^{*}$ \\
\hline Add'l Cntrls & & & & & & & & \\
\hline Chk. Acct. Yrs. & 0.000 & -0.000 & $-0.002 * * *$ & $-0.001^{* *}$ & 0.001 & 0.001 & $0.001^{* * *}$ & $0.001^{* * *}$ \\
\hline Cred. Rewards & & $0.165^{* * *}$ & & $-0.127 * * *$ & & $-0.020^{*}$ & & $-0.019^{* *}$ \\
\hline Deb. Rewards & & $-0.092^{* * *}$ & & $0.124^{* * *}$ & & -0.019 & & $-0.014^{*}$ \\
\hline Constant & $0.177^{* * *}$ & $0.148^{* * *}$ & $0.427^{* * *}$ & $0.458^{* * *}$ & $0.270^{* * *}$ & $0.269^{* * *}$ & $0.126^{* * *}$ & $0.124^{* * *}$ \\
\hline $\mathrm{N}$ & 1880 & 1722 & 1880 & 1722 & 1880 & 1722 & 1880 & 1722 \\
\hline R-Squared & 0.121 & 0.214 & 0.086 & 0.126 & 0.062 & 0.065 & 0.070 & 0.072 \\
\hline
\end{tabular}

Notes: Robust standard errors in parentheses. Dependent variable: fraction of payments made with credit card (Columns 1 and 2), debit card (Columns 3 and 4), cash (Columns 5 and 6) and check (Columns 7 and 8).

Level of significance: ${ }^{*} p<0.1,{ }^{* *} p<0.05,{ }^{* * *} p<0.01$ 


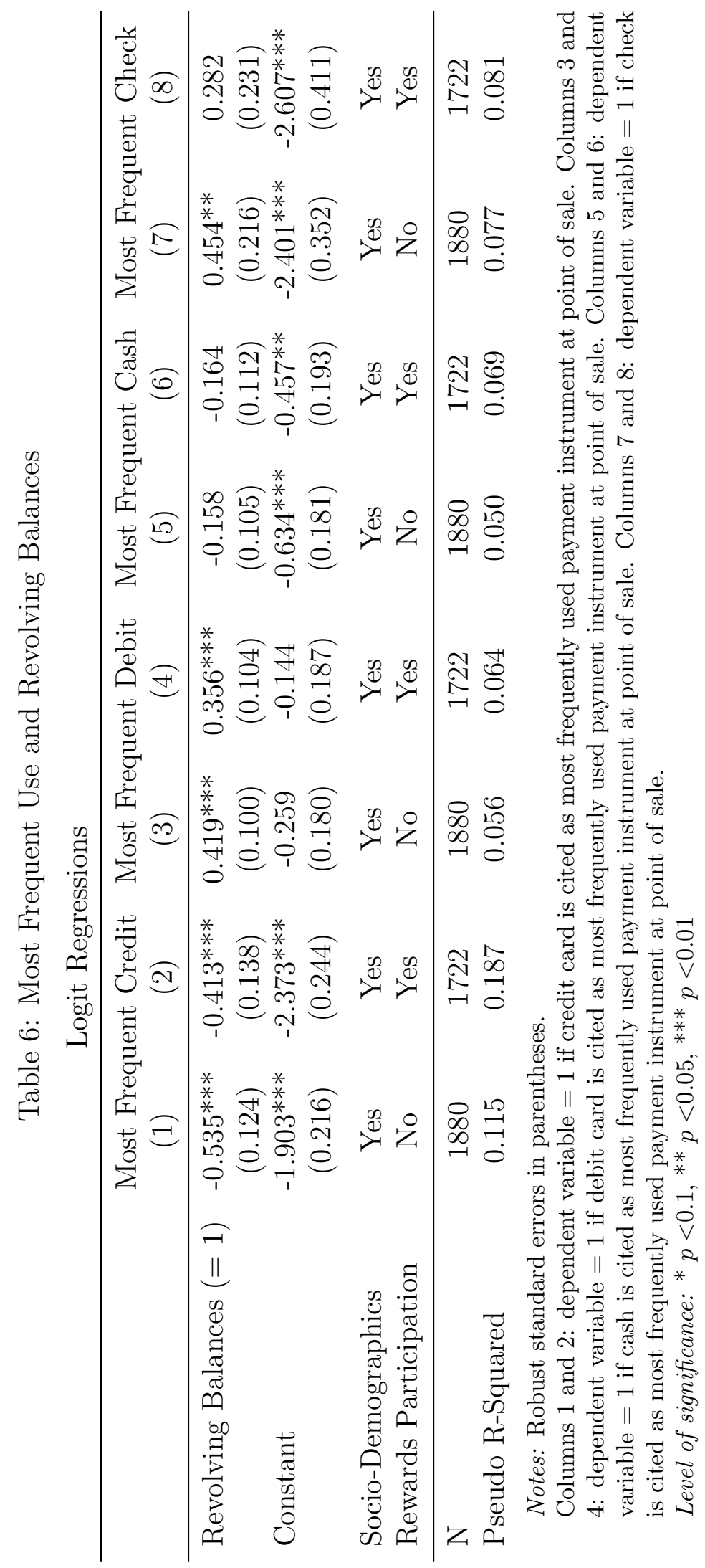


Table 7: Most Frequent Use and Revolving Balances

\begin{tabular}{|c|c|c|c|c|c|c|c|c|}
\hline & (1) & $(2)$ & (3) & (4) & (5) & (6) & (7) & (8) \\
\hline $\begin{array}{l}\text { Revolving } \\
\text { Balances }(=1)\end{array}$ & $-0.535^{* * *}$ & $-0.413^{* * *}$ & $0.419^{* * *}$ & $0.356^{* * *}$ & -0.158 & -0.164 & $0.454^{* *}$ & 0.282 \\
\hline $\begin{array}{l}\text { Male } \\
\text { Age }\end{array}$ & $0.308^{* *}$ & $0.338^{* *}$ & $-0.332^{* * *}$ & $-0.320^{* * *}$ & $0.298^{* * *}$ & $0.311^{* * *}$ & $-0.733^{* * *}$ & $-0.925^{* * *}$ \\
\hline $\begin{array}{l}\text { Over } 65 \text { yrs } \\
55-64 \text { yrs }\end{array}$ & $0.467^{* *}$ & 0.372 & $-0.402^{*}$ & -0.271 & -0.065 & -0.090 & 0.084 & 0.161 \\
\hline $45-54$ yrs & -0.268 & -0.330 & 0.128 & 0.141 & 0.171 & 0.092 & -0.418 & -0.216 \\
\hline $\begin{array}{l}35-44 \text { yrs } \\
25-34 \text { yrs }\end{array}$ & $\begin{array}{l}-0.051 \\
-0.019\end{array}$ & $\begin{array}{l}-0.166 \\
-0.158\end{array}$ & $\begin{array}{c}0.259^{*} \\
0.524^{* * *}\end{array}$ & $\begin{array}{c}0.271^{*} \\
0.557^{* * *}\end{array}$ & $\begin{array}{c}-0.196 \\
-0.365^{* *}\end{array}$ & $\begin{array}{c}-0.193 \\
-0.416^{* *}\end{array}$ & $\begin{array}{c}-0.120 \\
-1.169^{* * *}\end{array}$ & $\begin{array}{c}-0.021 \\
-0.876^{* *}\end{array}$ \\
\hline $18-24$ yrs & 0.200 & 0.187 & 0.172 & 0.171 & -0.060 & -0.094 & $-1.888^{*}$ & -1.622 \\
\hline Race & & & & & & & & \\
\hline Other & -0.448 & -0.374 & 0.292 & 0.222 & 0.107 & 0.084 & -0.709 & -0.551 \\
\hline $\begin{array}{l}\text { Hispanic } \\
\text { White }\end{array}$ & -0.012 & 0.330 & 0.189 & 0.087 & -0.072 & -0.210 & -1.042 & -0.848 \\
\hline Asian & $1.316^{* * *}$ & $1.459^{* * *}$ & $-1.343^{* * *}$ & $-1.383^{* * *}$ & -0.174 & -0.082 & -0.589 & -0.405 \\
\hline Black & $-0.687^{* * *}$ & $-0.430^{*}$ & -0.165 & $-0.285^{*}$ & $0.679^{* * *}$ & $0.633^{* * *}$ & -0.572 & -0.424 \\
\hline Income & & & & & & & & \\
\hline$>\$ 150 \mathrm{~K}$ & $1.105^{* * *}$ & 0.548 & -0.113 & 0.102 & $-0.879^{* *}$ & -0.544 & -0.641 & $\begin{array}{l}-0.783 \\
-0.299\end{array}$ \\
\hline$\$ 100-\$ 149 \mathrm{~K}$ & $858^{* * *}$ & $0.654^{* * *}$ & -0.099 & -0.044 & -0.47 & -0.3 & -0.6 & -0.299 \\
\hline$\$ 60-\$$ & $0.524^{* * *}$ & $0.403^{* *}$ & 0.090 & 0.159 & $-0.393^{* * *}$ & $-0.419^{* * *}$ & -0.348 & -0.120 \\
\hline$\$ 40-\$ 59 \mathrm{~K}$ & 0.195 & 0.177 & 0.110 & 0.180 & -0.194 & $-0.262^{*}$ & -0.111 & -0.034 \\
\hline$\$ 20-$ & & & & & & & & \\
\hline $\begin{array}{l}<\$ 20 \mathrm{~K} \\
\text { Education }\end{array}$ & 0.115 & $0.432^{*}$ & $-0.391^{* *}$ & $-0.425^{* *}$ & $0.301^{*}$ & 0.128 & -0.130 & 0.074 \\
\hline Grad. School & $0.962^{* * *}$ & $0.775^{* * *}$ & $-0.442^{* * *}$ & $-0.388^{* *}$ & $-0.551^{* * *}$ & $-0.475^{* *}$ & 0.514 & $0.848^{* *}$ \\
\hline $\begin{array}{l}\text { College } \\
\text { Some College }\end{array}$ & $0.527^{* * *}$ & $0.423^{* * *}$ & -0.126 & -0.093 & $-0.296^{* *}$ & $-0.269^{*}$ & 0.148 & 0.340 \\
\hline High School & -0.298 & -0.305 & $-0.454^{* * *}$ & $-0.475 * * *$ & $0.418^{* * *}$ & $0.448^{* * *}$ & $0.579^{* *}$ & $0.632^{*}$ \\
\hline Some HS & -0.798 & -0.667 & 0.030 & -0.184 & 0.260 & 0.336 & 0.543 & 0.605 \\
\hline & & & & & & & & \\
\hline Chk. Acct. Yrs. & 0.008 & 0.006 & $-0.014^{* *}$ & -0.010 & 0.008 & 0.006 & -0.001 & 0.002 \\
\hline Cred. Rewards & & $1.662^{* * *}$ & & $-0.595^{* * *}$ & & $-0.782^{* * *}$ & & $-0.609^{*}$ \\
\hline Deb. Rewards & & $-0.776^{* * *}$ & & $0.664^{* * *}$ & & 0.013 & & -0.122 \\
\hline Constant & $-1.903^{* * *}$ & $-2.373^{* * *}$ & -0.259 & -0.144 & $-0.634^{* * *}$ & $-0.457^{* *}$ & $-2.401^{* * *}$ & $-2.607^{* * *}$ \\
\hline $\begin{array}{l}\mathrm{N} \\
\text { Pseudo }\end{array}$ & 1880 & 1722 & 1880 & 1722 & 1880 & 1722 & 1880 & 1722 \\
\hline R-Squared & 0.115 & 0.187 & 0.056 & 0.064 & 0.050 & 0.069 & 0.077 & 0.081 \\
\hline
\end{tabular}




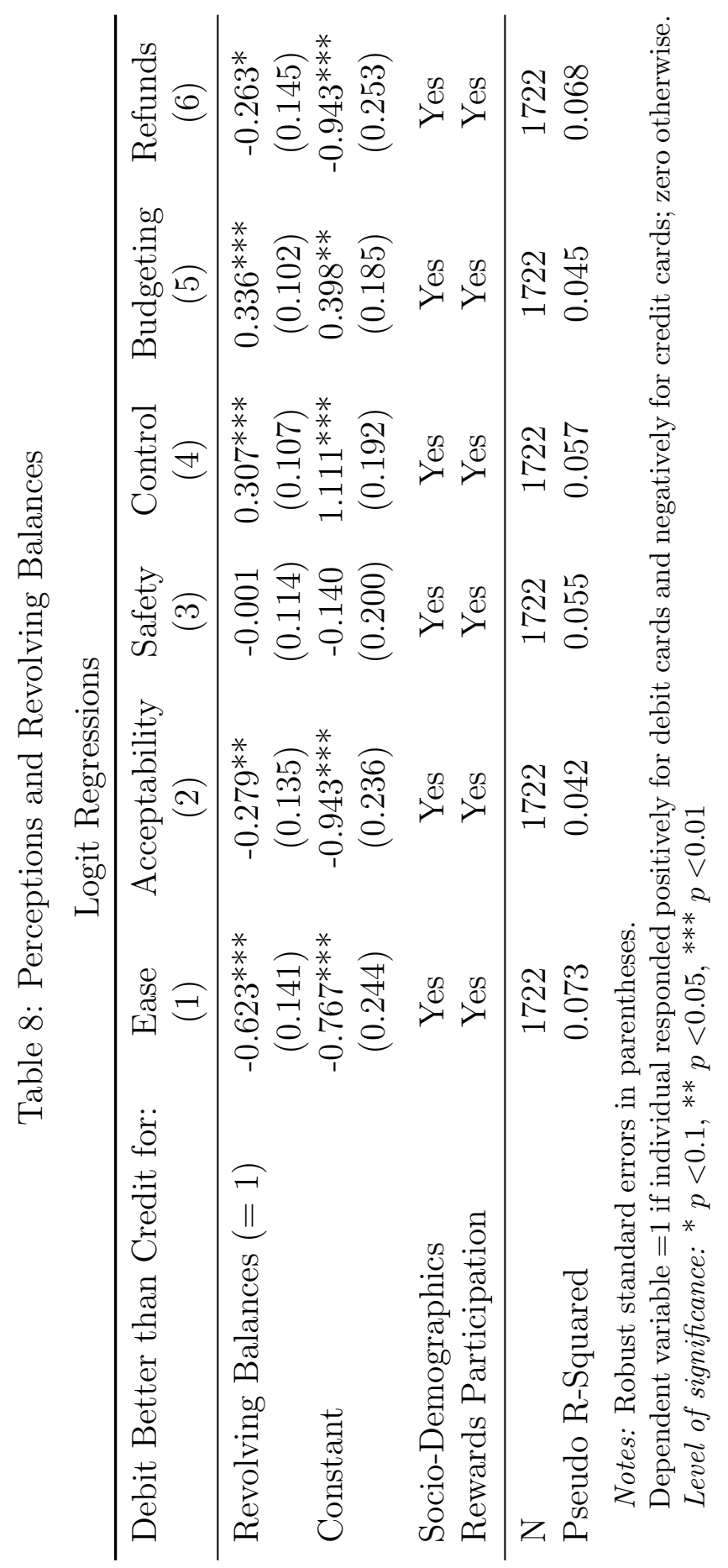


Table 9: Perceptions and Revolving Balances

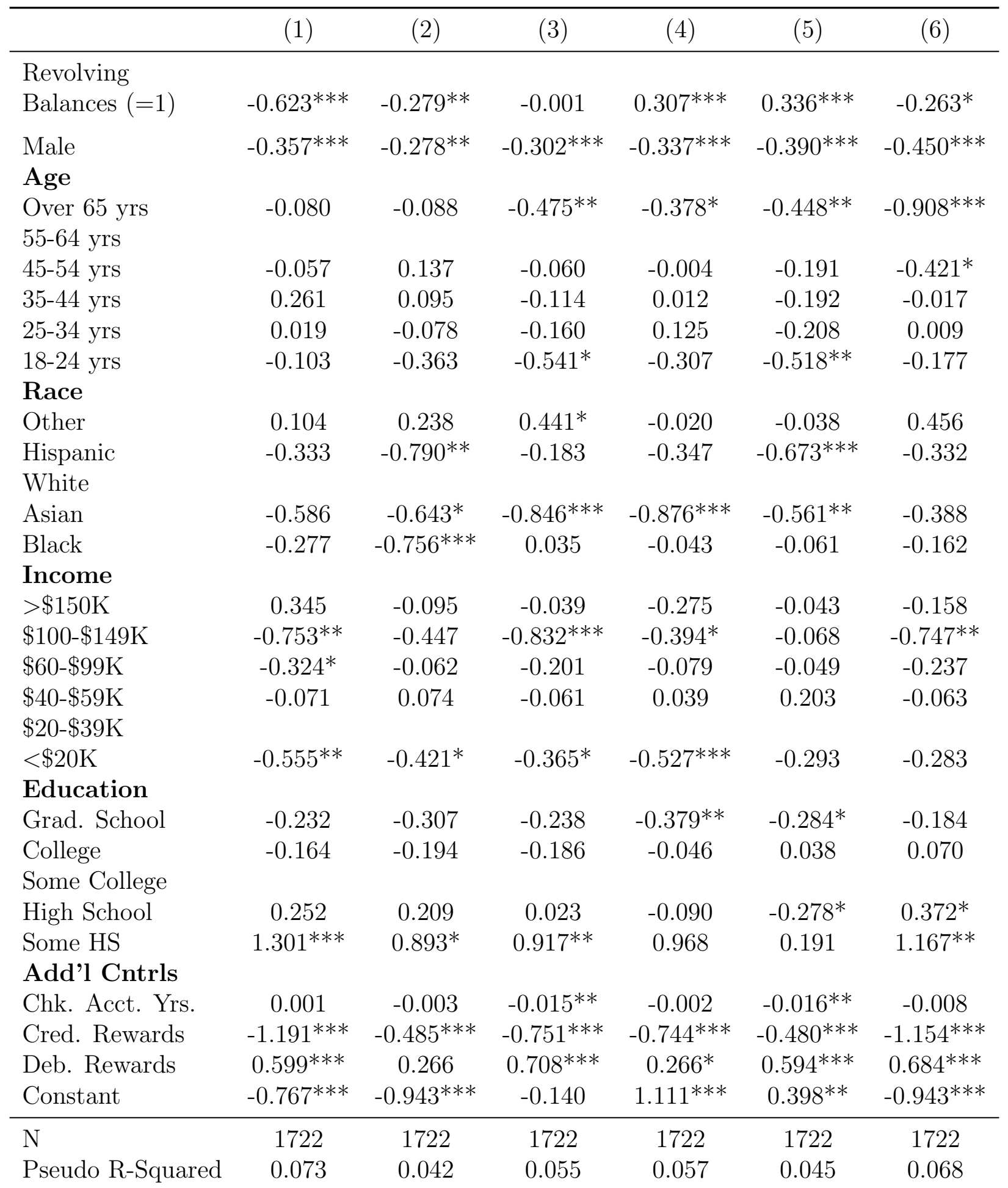

Notes: Dependent variable $=1$ if individual responded positively for debit cards and negatively for credit cards; zero otherwise. Column 1 is ease, column 2 is acceptability, column 3 is safety, column 4 is control, column 5 is budgeting, and column 6 is refunds.

Level of significance: ${ }^{*} p<0.1,{ }^{* *} p<0.05,{ }^{* * *} p<0.01$ 
Table 10: Fraction of Consumers with Credit and Debit Card Rewards

\begin{tabular}{lcccc}
\hline Variable & $\begin{array}{c}\text { Total } \\
\mathrm{N}=1722\end{array}$ & $\begin{array}{c}\text { Non-Revolvers } \\
\mathrm{N}=964\end{array}$ & $\begin{array}{c}\text { Revolvers } \\
\mathrm{N}=758\end{array}$ & $\begin{array}{c}\mathrm{p} \text {-value } \\
\text { from t-test }\end{array}$ \\
\hline & & & & \\
Credit Card Rewards & .305 & .303 & .309 & .796 \\
Debit Card Rewards & .146 & .122 & .175 & .002
\end{tabular}

Table 11: Fraction of Consumers with Payment Perceptions

\begin{tabular}{lcccc}
\hline Variable & $\begin{array}{c}\text { Total } \\
\mathrm{N}=1880\end{array}$ & $\begin{array}{c}\text { Non-Revolvers } \\
\mathrm{N}=1073\end{array}$ & $\begin{array}{c}\text { Revolvers } \\
\mathrm{N}=807\end{array}$ & $\begin{array}{c}\text { p-value } \\
\text { from t-test }\end{array}$ \\
\hline Credit Card & & & & \\
Easy & .740 & .698 & .796 & .000 \\
Acceptability & .580 & .555 & .612 & .014 \\
Safe & .398 & .401 & .395 & .811 \\
Control & .298 & .324 & .263 & .004 \\
Budget & .179 & .207 & .143 & .000 \\
Refund & .655 & .625 & .694 & .002 \\
Debit Card & & & & \\
Easy & .723 & .671 & .792 & .000 \\
Acceptability & .506 & .486 & .533 & .042 \\
Safe & .482 & .452 & .523 & .002 \\
Control & .851 & .829 & .880 & .002 \\
Budget & .504 & .473 & .545 & .002 \\
Refund & .493 & .451 & .549 & .000 \\
Cash & & & & \\
Easy & .894 & .887 & .902 & .301 \\
Acceptability & .765 & .772 & .757 & .462 \\
Safe & .552 & .548 & .558 & .678 \\
Control & .662 & .646 & .684 & .083 \\
Budget & .604 & .594 & .618 & .279 \\
Refund & .567 & .562 & .574 & .611 \\
Check & & & & \\
Easy & .269 & .259 & .283 & .257 \\
Acceptability & .072 & .075 & .068 & .595 \\
Safe & .225 & .22 & .229 & .703 \\
Control & .384 & .365 & .409 & .054 \\
Budget & .303 & .285 & .326 & .057 \\
Refund & .171 & .185 & .152 & .067 \\
& & & &
\end{tabular}




\section{Appendix: Construction of Perceptions Variables}

The SCPP asks respondents to fill in a grid below to indicate their perceptions of each payment instrument. The respondents can check as many cells as they want to show whether they agree with a given statement. The grid is introduced as follows:

Please select all the methods of payment for in-store purchases that you believe fit the following descriptions: (You may select more than one in each row.)

\begin{tabular}{|c|c|c|c|c|c|c|}
\hline & Cash & $\begin{array}{l}\text { Paper } \\
\text { Check }\end{array}$ & $\begin{array}{c}\text { Credit } \\
\text { Card }\end{array}$ & $\begin{array}{l}\text { Debit Card; } \\
\text { enter PIN }\end{array}$ & $\begin{array}{l}\text { Debit Card; } \\
\text { sign receipt }\end{array}$ & $\begin{array}{c}\text { Gift/ } \\
\text { Prepaid Card }\end{array}$ \\
\hline \multicolumn{7}{|l|}{ 1) Is convenient } \\
\hline \multicolumn{7}{|l|}{ 2) Is easy to use } \\
\hline \multicolumn{7}{|l|}{$\begin{array}{l}\text { 3) Is preferred by } \\
\text { stores/sales people }\end{array}$} \\
\hline \multicolumn{7}{|l|}{$\begin{array}{l}\text { 4) Keeps my money/accounts } \\
\text { safe }\end{array}$} \\
\hline \multicolumn{7}{|l|}{$\begin{array}{l}\text { 5) Money leaves my } \\
\text { account right away }\end{array}$} \\
\hline \multicolumn{7}{|l|}{$\begin{array}{l}\text { 6) Helps me budget/spend } \\
\text { within my means }\end{array}$} \\
\hline \multicolumn{7}{|l|}{$\begin{array}{l}\text { 7) Gives me control } \\
\text { over my money }\end{array}$} \\
\hline $\begin{array}{l}\text { 8) Is easy to get a refund } \\
\text { for returned items/disputes }\end{array}$ & & & & & & \\
\hline
\end{tabular}

It is not required that an individual respondent be a user of a particular instrument for him/her to register his/her perceptions. In order to develop the variables for each payment instrument we used the following mapping:

a) "Yes" for the first and second perceptions map into a dummy variable, easy to use. 
b) "Yes" for the third perception maps into a dummy variable, widely acceptable.

c) "Yes" for the fourth perception maps into a dummy variable, safe.

d) "Yes" for the fifth and seventh perceptions map into a dummy variable, allowing control over money.

e) "Yes" for the sixth perception maps into a dummy variable, helping in budgeting.

f) "Yes" for the eighth perception maps into a dummy variable, easy to get refunds. 